\title{
Correction to: Acquired Immunity in Metal Allergy: T Cell Responses
}

\author{
Trine Hilkjær Petersen, Carsten Geisler, \\ and Charlotte Menné Bonefeld
}

\section{Correction to: \\ Chapter 9 in: J. K. Chen, J. P. Thyssen (eds.), Metal Allergy, https://doi.org/10.1007/978-3-319-58503-1}

The author name was inadvertently published as "By Trine Hilkjær Petersen" in the table of contents and chapter 9.

This has now been amended throughout the book as Trine Hilkjær Petersen

The updated online version of the original chapter can be found at https://doi.org/10.1007/978-3-319-58503-1_9

T. H. Petersen · C. Geisler · C. M. Bonefeld $(\bowtie)$ Department of Immunology and Microbiology, Faculty of Health and Medical Sciences, University of Copenhagen, Copenhagen, Denmark e-mail: cmenne@sund.ku.dk 